\title{
Research on the promotion of football culture to campus culture
}

\author{
Hong-chun Jia ${ }^{1, a}$, Song-bo $\mathrm{He}^{1, \mathrm{~b}, *}$, Ruo-chen li ${ }^{2, c}$ \\ ${ }^{1}$ Beihua University ,Jilin, China \\ ${ }^{2}$ Beihua University, College of physical education, Longteng innovation and entrepreneurship \\ education base \\ *Corresponding author
}

Keywords: football; campus culture; promoting role

\begin{abstract}
. campus football culture is an important part of sports culture, and it is an important content and form of campus culture. Through the campus football culture, how to educate people, exercise people, cultivate people and so on, to explain its impact on campus culture. It can make people realize the promoting effect of campus football culture on campus culture, so as to attach importance to the construction of campus football culture.
\end{abstract}

\section{Introduction}

Twenty-first Century will be a century of culture shock, the society began the transition from economy to culture, social culture is infiltrating into all areas of life, cultural phenomena emerge in an endless stream of football culture is just unfolding in different poses and with different expressions. Chinese football World Cup final success impact, shows the "Happy football" Milutinovic football culture and thought. The spirit of sports and team spirit in football is the common ideal and pursuit of human society, and also the basis of human society.

Football is not a simple "bounce" recreational activities, is not a purely physical exercise, sports and games, its significance is beyond the scope and nature of sports, is a manifestation of sports culture and values.

\section{Campus culture}

The school is a very special group: young students, full of youthful spirit; some experts and scholars of the library information resources of noble character and high prestige; rich; advanced media; there are many groups and student organizations etc.. These constitute a unique, high level of cultural standards and a relatively complete cultural environment, which contains great cultural creativity. At the same time, campus is the place where many new ideas, new trends of thought, new ideas and new information are accepted, spread or born. This atmosphere is rich in cultural resources, and has a great educational function. Campus culture as a unique social phenomenon of sub culture, is the campus space, with students and teachers for the participants to extracurricular activities as the main content, to the more scientific and cultural fields extensive exchanges and special life rhythm as the basic form, a kind of group culture with the characteristics of the times. At the same time, the campus culture is a multi-level, three-dimensional culture, cultural category covers many aspects of material culture, spiritual culture, living culture, art culture, behavior culture, sports culture, community culture, science culture, psychological culture etc.. 


\section{Campus football culture}

There is a football as a kind of culture, it can meet the need of people's physical health, but also to meet the spiritual needs of people, is also a kind of social and cultural needs; method is a kind of fitness and entertainment, and is the inheritance and development of a social culture and influence. It is a kind of group culture which takes students as the main part and takes extracurricular football cultural activities as the main content, takes the campus as the main space, takes the campus spirit as the main characteristic. The content of this particular cultural atmosphere and training target, school spirit and life style related. Campus football culture is a unique cultural phenomenon with profound connotation and rich extension. Campus football culture and campus basketball, track and field together constitute the campus sports culture group.

Campus football culture is the sum of soccer spirit, wealth and material wealth created in the course of teaching and scientific research. That is, all the material and spiritual wealth, as well as related concepts and consciousness, formed and owned by the staff and students of the school in the activities of football teaching, body-building, sports competitions and sports facilities construction. It is a kind of group culture which takes students as the main part and takes extracurricular football cultural activities as the main content, takes the campus as the main space, takes the campus spirit as the main characteristic.

\section{The role of campus football culture}

As a kind of social culture, campus football culture is gradually formed in the course of long-term teaching practice. It is developed under the direct participation and careful training of the majority of teachers and students. It is to improve students' intelligence structure, strengthen the communication of school and society, inheritance, reference of civilization of human society, to improve their enthusiasm, initiative and creativity, has its special status and function to promote the further development of education reform.

\subsection{Football culture is the most important part of campus sports culture.}

Campus football culture is a cultural form existing in the specific environment of school. Fair competition and cooperation, unremitting self-improvement, self-confidence is not only the essence of the spirit of football, with its charm and its unique role in the development of students' physical and mental health play a powerful influence on the subtle, became the campus sports culture on the internal and external display window. "Faster, higher, stronger", "unity, friendship, progress", "emphasis on participation", "fair competition" and other Olympic spirit, its charm is hidden in the sports culture. Sports and sports culture are the most active, the most active, the longest, the longest and the most far-reaching cultural activities in campus culture.

\subsection{Football is an important part of sports culture festival.}

Campus Sports Culture Festival is the best carrier to spread values, and it is an effective means to stimulate students' interest in football. It combines football's sensibility and cultural reason, integrates football knowledge, football game, football performance, football match, football photography and so on. Football activities as the carrier, for teachers and students to provide a platform, to fair competition, unity and cooperation, and strive for progress as the purpose, to 
"health, happiness, civilization" as the goal, to train the quality of football teachers and students. Because the Football Festival has a strong festival atmosphere, it can improve the students' interest and attract the students to participate actively. Through the sports culture festival, soccer is not only a means of physical exercise and physical fitness, but also a kind of enjoyment, a kind of pleasure and an experience. In this warm and passionate cultural atmosphere, more and more people are attracted, supported and participated in football. The school sports festival, the student's own festival, will be a model for the successful practice of quality education in the field of school sports.

\section{The role of campus football culture in the construction of campus culture}

Football and football culture is conducive to the cultivation of people hard work, never climbed the peak of the spirit; to promote unity and cooperation, fair competition in the society; to set up the national self-esteem, self-confidence and pride, enhance their sense of patriotism and collectivism; to promote students' physical and mental health. In a word, football plays an important role in inspiring spirit, enhancing students' cohesive force, improving students' moral quality, displaying the image of the school and promoting the school's level.

\subsection{Campus football culture's educational role in campus culture.}

The campus football culture not only has rich sports knowledge, self-cultivation, health communication, and create a healthy, active and lively atmosphere of the campus culture, for students to build a full display of talent and expertise to the platform. More importantly, through the rich and colorful activities, to cultivate the students' ability of organization, enhance the participation of students, promote the formation of students' personality and improve eye sense of attitude and value, improve the students' moral cultivation. In carrying forward the positive campus sports culture fumigation, in the selfless struggle, exercise the will character, edify the sentiment, the soul can be purified, personality can be sublimated. This will play a very active role in the physical and mental health of students.

\subsection{Campus football culture has the function of humanistic quality education in campus culture}

Humanistic quality education is to educate people's spiritual realm, personality, grade, and even national spirit. The spread of football culture included in sports is to promote the humanistic spirit that conforms to the social development. Campus football culture is a spiritual force to maintain the school community. It plays an important role in cultivating campus spirit, promoting spiritual civilization construction, creating school humanistic atmosphere and humanistic atmosphere. So to make full use of sports culture resources, people-oriented, let the students participate in the campus football body through cultural activities, to understand the society, to contact the society, culture of unity and cooperation, hard work, enterprising spirit, respect the facts, advocating rational spirit. The campus culture to cultivate students' good personality, good optimistic attitude, calm, not arrogance and rashness, and failed as the main content.

Football is a cooperative collective game, in a good atmosphere, students can enhance their collective consciousness and learn to cooperate and respect each other. The development of football activities in school life, students can develop the ability to get along with people, with people. Football activities can help people to provide a platform to showcase, and emphasizes the mutual 
support and mutual cooperation team spirit, for students to properly handle the relationship between the individual and the collective interests of the positive guidance.

\section{Acknowledgements}

This paper is a research project of Beihua University students' innovation project, horizontal to pic: Dragon Boat land training equipment (NO:201602014).

\section{References}

[1]. Zhou Jingdong. The secondary occupation school campus football culture construction -Taking Jiangsu Province as an example [D]. Huishan Vocational School of Soochow University.2015.

[2]. Hu Chaowen. Fusion and inheritance of dragon dance culture and campus culture [J]..2015.

[3]. Liang Jiannan. Research on the development of football in Guangxi Higher Vocational Colleges

[J]. contemporary sports science and technology,.2015.

[4]., Wang Zhimin, Liu Wei, Zhao Guocheng. Strategy Research on campus soccer culture [J]. mass literature and art.2014.

[5]., Wu Zuo. The role of university football culture in the construction of harmonious campus [J]. intelligence.2014.

[6]., Gao Xiang. Exploring the development of "campus football" movement -- Taking Nanchang primary and middle schools as an example, [D], East China Jiaotong University,.2012.

[7] Guo. Xiangjie. In ordinary universities of Henan Province Campus football competition to carry out the investigation of Henan University [D].2012. 